\title{
Mark To Market Accounting: Does It Provide Information To Investors
}

\author{
Charles Harter, Ph.D., CPA, Georgia Southern University, USA
}

\begin{abstract}
According to the financial press the recent financial problems of many firms is at least partially due to mark-to-market accounting. In this paper I ask the question -- if mark-to-market accounting is the reason for the financial distress of firms, why does the FASB require mark-tomarket? I review accounting standards that require mark-to-market accounting and empirically test the relation between firm value and mark to market adjustments to provide evidence as to whether mark-to-market adjustments are useful to investors and creditors. The results provide evidence that mark-to-market adjustments impact firm value.
\end{abstract}

Keywords: Mark-to-market, firm value, net charge-offs

\section{INTRODUCTION}

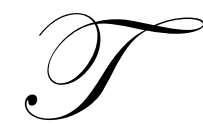

he current economic crisis has seen a significant numbers of firms in financial distress. These firms have asked for bailouts from the federal government, filed for bankruptcy, or liquidated. There are numerous reasons for the financial distress of these firms. However, according to the financial press, the problems encountered by firms are exacerbated by mark-to-market accounting. In this paper I ask the question -if mark-to-market accounting is the reason for the financial distress of firms, why does the FASB require mark-tomarket? I review accounting standards that require mark-to-market accounting and empirically test the relation between firm value and mark to market adjustments to provide evidence as to whether mark-to-market adjustments are useful to investors and creditors.

\section{EVOLUTION OF STANDARDS THAT REQUIRE MARK-TO-MARKET}

According to the conceptual framework issued by the FASB, in order for accounting information to be useful for decision making it must meet two primary qualitative characteristics; relevance and reliability. Historical cost information is generally reliable because it can be verified through the use of invoices and other source documents. However, historical cost information can be outdated. Outdated information may not be as useful in decision making as current fair market value information. Unfortunately, determination of fair market value may require the use of subjective estimates. Fair market value can be relevant to decision makers, but its subjectivity reduces its reliability.

Prior to 1993, standard setters focused primarily on the reliability of financial reporting, requiring financial statements to be presented on a historical cost basis. White (1991) advocated the use of market value accounting even at the expense of estimation errors. He recognized that market value accounting is not perfect, but its use would permit the balance sheet to come closer to the concept of "market value of net worth". He argued that the purpose of an accounting system is to present the current economic reality of a corporation so private and public decisions have a proper basis. In May 1993, the FASB issued Statement of Financial Accounting Standard Number 115 that required the use of fair market value for investments in debt and equity securities that were considered trading or available for sale securities. Under SFAS 115 unrealized gains or losses due to fair market value adjustments are required to be disclosed in the income statement or in the statement of comprehensive income depending upon the classification of the securities as trading or available for sale. SFAS 115 maintained amortized cost for debt securities that management intends to hold to maturity. While SFAS 115 is a deviation from historical 
cost, it still provides reliable information because most debt and equity securities are traded on exchanges that provide a reliable measure of fair market value.

In June 1998 the disclosure of fair market value information on the balance sheet was expanded when the FASB issued Statement of Accounting Standards Number 133 "Accounting for Derivative Instruments and Hedging Activities". This standard requires that all derivative instruments be shown on the balance sheet at fair market value. Under this standard gains or losses arising from changes in fair market value of derivative securities must disclosed in the income statement or as part of comprehensive income depending on whether the security is used for hedging or speculation. Derivatives may have little or no cost, and in many cases there is no market that can be used to determine fair market value. Financial statement preparers must estimate fair value using discounted cash flows or other means. Clearly, with the issuance of this standard financial reporting has moved further toward fair value.

In August 2001 fair value financial reporting was expanded with the issuance of SFAS 144 "Accounting for the Impairment or Disposal of Long-Lived Assets". This standard requires recognition of impairment losses on long-lived assets if the carrying value is not recoverable from its undiscounted cash flows. Measurement of the impairment loss is the difference between the carrying amount and the fair value of the asset. The standard refers to FASB Concepts Statement number 7 with regard to measurement of fair market value using present value techniques.

Recognizing the importance of fair market value, in September 2006 the FASB issued Statement of Accounting Standards Number 157, "Fair Value Measurements". This standard is intended to provide consistency in financial reporting by providing a single definition of fair value, establishing a framework for measuring fair market value, and expanding required disclosures about fair value measurements. This standard provides guidance for all fair value measurements including measurement of impairment of assets. The standard presents a hierarchy of inputs to establish fair value for assets and liabilities. The inputs used to determine fair value vary depending upon whether the asset or liability is actively traded in a market, has similar assets traded on an active market or must be based on unobservable inputs based upon the entities own assumptions.

\section{EMPIRICAL TEST OF USEFULNESS OF MARK-TO-MARKET}

Accountants and accounting regulators have defended mark-to-market accounting because it represents most closely changes in the firm's asset and liability values. However, because standards requiring fair market value reporting are fairly recent, there has been little research investigating the impact that these standards have had on investors. In order to obtain some understanding of the impact of mark-to-market accounting on investors and firm value I use net write-offs as a proxy for charge-offs due to mark-to-market. Net charge-offs, provided in the COMPUSTAT database, represents the reported amount of asset write-downs minus recoveries of previous writedowns. If losses exceed recoveries, net charge-offs is shown as a negative amount. Gains and losses resulting from mark to market adjustments are likely to be included in this variable. Therefore, using net charge-offs as a proxy for mark to market adjustments, I investigate the effect of mark to market adjustments on investor beliefs about the fundamental value of the stock.

The incremental impact of mark to market adjustments is examined using the association between stock prices and accounting information with and without write-offs. A significant result will provide evidence that mark to market adjustments provide information useful in determining firm value. If mark to market is not value relevant, and simply provides noise as suggested by those not in favor of mark to market accounting, the FASB should be encouraged to eliminate the requirement for mark to market. On the other hand, significant results would provide evidence that mark to market accounting should be maintained.

\section{HYPOTHESIS AND RESEARCH DESIGN}

Previous studies have looked at the value relevance of accounting information using $\mathrm{R}^{2}$ or coefficients on regression explanatory variables using earnings, change in earnings, and book value, and stock prices or returns. Chiang and Venkatesh (1988); Lev and Zarowin (1999); Francis and Schipper (1999); and Brown, Lo, and Lys (1999). Collins, Maydew, and Weiss (1997) find that the incremental value-relevance of earnings (book value) 
declines (increases) in the frequency of nonrecurring items and negative earnings, suggesting that the conventional historical cost accounting model is relevant. In the current study I use a similar methodology to investigate the usefulness of mark to market accounting.

The impact of mark to market adjustments on firm value is empirically examined by regressing stock prices on earnings and book values. Earnings and book value encapsulate accounting information. Net charge-offs are used as a proxy for mark to market adjustments because mark to market necessitates write-offs that are included in this compustat variable. Consistent with the prediction, I find that charge-offs are positively related to firm value; having a significant positive coefficient. These results indicate that investors do attribute mark-to-market accounting with changes in firm value.

The observed association between stock prices and value-relevant accounting information is examined both with and without net charge-offs. My hypothesis is based on the theoretical relation between accounting information and firm value.

Hypothesis: The increase in association between accounting information and stock price as measured by the $\mathrm{R}^{2}$ and the regression coefficient on net charge-offs is due to the value relevance of mark to market adjustments.

To test this hypothesis, I use the approach of Collins, Pincus, and Xie 1999, based on the Ohlson 1995 model, which expresses the stock price as a function of its earnings and book value.

$\mathrm{MV}_{i t}=a_{0 t}+a_{l t} \mathrm{BV}_{i t}+a_{2 t} \mathrm{NI}_{i t}+a_{3 t} \mathrm{CHGOFF}_{i t}+$ error $_{i t}$

Where $\mathrm{MV}_{i t}$ is the market value of firm $i$ three months after fiscal year-end of year $t ; \mathrm{BV}_{i t}$ is the book value of equity of firm $i$ at fiscal year-end $t$; and $\mathrm{CHGOFF}_{i t}$ is the net charge-offs for firm $i$ in year $t$. All variables are scaled by total assets to control for scale effects.

\section{THE SAMPLE AND THE RESULTS}

The sample consists of all firms in the COMPUSTAT industrials Annual Database from 2002 to 2005 having data on income before extraordinary items (data item 18), total assets (data item 6), common equity (data item 60), common shares outstanding (data item 25), and net charge offs (data item 349). Stock price data is obtained from the CRSP data base. The final sample is made up of 838 observations. The relatively small sample is due to the limited number of firms that report net charge offs. Descriptive statistics for all variables for each year are presented in table 1. Net charge-offs includes the write-off of assets and the recovery of previous asset writeoffs. As expected, the average charge-off is negative.

In table 2 the results of the regressions are presented. Panel A presents results without charge-offs. The independent variable, market value, is computed by multiplying common shares outstanding by stock price three months after year end. Net income is computed by subtracting charge-offs from income before extraordinary items. Net book value includes total stockholders equity divided by total assets. Coefficients on both Net Income and Book Value are positive and significant at the .0001 level. Adjusted $\mathrm{R}^{2}$ is .159.

Panel B of table 2 presents results with chargeoffs included in the regression. As with the other variables, Net chargeoffs are scaled by total assets. The coefficient on net chargeoffs is positive and significant at the .0001 level. This result indicates that the proxy for mark to market write-offs, net chargeoffs, is significant and positively related to firm value. $\mathrm{R}^{2}$ increased to .187 , providing further evidence that write-offs impact on firm value.

To determine if the results are consistent from year to year I next separate the sample by year. The sample size for each year ranges from 201 for the year 2002 to 218 for the year 2005 . The coefficients on the variables for net charge-offs are significant at the .05 level or better for every year. For the years 2004 and 2005 the coefficients are significant at the .0001 level. Results are presented in Table 3. It is interesting that the coefficient for chargeoffs is more significant in later years. SFAS 144 did not become effective until December 15, 2001. Perhaps investors had more confidence in fair value adjustments as they became more familiar with the information. 


\section{IMPLICATIONS}

According to the Conceptual Framework developed by the FASB, accounting information should provide information that is useful to investors and creditors. White (1991) advocated the use of market value accounting even at the expense of some estimation errors. According to him, fair value would permit the balance sheet to come closer to the concept of "market value of net worth". He argued that the purpose of an accounting system is to present the current economic reality of a corporation so private and public decisions have a proper basis. This study provides evidence that mark to market accounting provides information that is correlated with firm value. These results suggest that mark to market adjustments provide information that is valuable to investors and creditors. Therefore, the disclosure of fair value information should be increased, not decreased as suggested by the financial press.

Table 1: Descriptive Statistics $2002--2005$

\begin{tabular}{|c|c|c|c|c|}
\hline Variable & Mean & Std. Dev. & Min. & Max. \\
\hline CHGOFF - 02 & -5.6420 & 187.8010 & -780.0000 & 2743.0000 \\
\hline CHGOFF - 03 & -17.2168 & 78.2000 & -828.5480 & 479.1700 \\
\hline CHGOFF - 04 & -15.5380 & 68.2526 & -767.1000 & 8.5550 \\
\hline CHGOFF - 05 & -15.1961 & 70.2656 & -759.9110 & 66.7900 \\
\hline NI - 02 & 95.2997 & 527.1704 & -995.2810 & 9419.0000 \\
\hline NI - 03 & 130.8879 & 650.2631 & -990.8000 & 9993.0000 \\
\hline NI - 04 & 157.8280 & 693.2627 & -947.0000 & 9983.0000 \\
\hline NI - 05 & 171.9329 & 710.0118 & -967.0000 & 9455.1200 \\
\hline BV - 02 & 531.5432 & 1340.0700 & -995.5840 & 9872.0000 \\
\hline BV - 03 & 550.5053 & 1363.4100 & -963.8370 & 9934.7300 \\
\hline BV - 04 & 578.6099 & 1380.7300 & -864.0940 & 9852.0000 \\
\hline BV - 05 & 600.5098 & 1412.4800 & -967.9740 & 9994.7600 \\
\hline Stk Price - 02 & 18.7291 & 23.7802 & .0600 & 681.3600 \\
\hline Stk Price - 03 & 25.0216 & 29.7720 & .1800 & 884.4100 \\
\hline Stk Price - 04 & 26.1881 & 36.0399 & .1800 & 1073.0000 \\
\hline Stk Price - 05 & 28.5668 & 42.6702 & .1500 & 1594.0000 \\
\hline Shares - 02 & 115.8996 & 458.9356 & 0.0 & 9969.8900 \\
\hline Shares - 03 & 114.4128 & 423.6534 & 0.0 & 8575.0000 \\
\hline Shares - 04 & 117.7758 & 420.5124 & 0.0 & 7473.0000 \\
\hline Shares - 05 & 120.0858 & 423.1823 & 0.0 & 9741.3400 \\
\hline
\end{tabular}

CHGOFF = Compustat item \#349, net charge-offs.

$\mathrm{NI}=$ Compustat item \#18, Income before extraordinary items.

$\mathrm{BV}=$ Compustat item \#60, Common equity.

$\mathrm{MV}=$ Stk price $\mathrm{x}$ common shares outstanding (stk price $\mathrm{x}$ Compustat item \#25)

Table 2: Accounting Information and Firm Value Full sample - years 2002 to 2005 $\mathbf{N}=838$

\begin{tabular}{|c|c|c|c|c|}
\multicolumn{2}{c}{ Without Chargeoffs } \\
\hline Variable & Coefficient & t-stat & Coefficient & t-stat \\
\hline Intercept $\mathrm{a}_{0}$ & .07 & 5.49 & .08 & 6.37 \\
\hline sgNI, $\mathrm{a}_{1}$ & 3.94 & 8.48 & 4.49 & 9.59 \\
\hline NBV $\mathrm{a}_{2}$ & 1.09 & 8.81 & 1.04 & 8.59 \\
\hline sChgoff, $\mathrm{a}_{3}$ & & & 8.47 & 5.42 \\
\hline Adj. $\mathrm{R}^{2}$ & & 15.89 & & 18.66 \\
\hline
\end{tabular}

$\mathrm{SMV}_{i t}=a_{0 t}+a_{1 t} \mathrm{NBV}_{i t}+a_{2 t} \mathrm{sgNI}_{i t}+a_{3 t} \mathrm{SCHGOFF}_{i t}+$ error $_{i t}$

$\mathrm{sMV}=$ Stk price $\mathrm{x}$ common shares outstanding/Total Assets

sgNI $=(\mathrm{NI}-$ Charge-offs $) /$ Total Assets

$\mathrm{NBV}=\mathrm{BV} /$ Total Assets

sChgoff $=$ Charge-offs/Total Assets 
Table 3: Accounting Information and Firm Value by year

2002, $\mathrm{N}-201$

\begin{tabular}{|c|c|c|c|c|}
\hline & \multicolumn{2}{|c|}{ Without Chargeoffs } & \multicolumn{2}{|c|}{ With Chargeoffs } \\
\hline Variable & Coefficient & t-stat & Coefficient & t-stat \\
\hline Intercept $\mathrm{a}_{0}$ & .07 & 2.32 & .08 & 2.68 \\
\hline sgNI, $a_{1}$ & 2.65 & 3.96 & 3.00 & 4.38 \\
\hline $\mathrm{NBV}, \mathrm{a}_{2}$ & 1.26 & 4.15 & 1.22 & 4.03 \\
\hline sChgoff, $\mathrm{a}_{3}$ & & & 6.17 & 2.06 \\
\hline Adj. $R^{2}$ & & 12.86 & & 14.27 \\
\hline
\end{tabular}

2003, N-210

\begin{tabular}{|c|c|c|c|c|}
\multicolumn{2}{|c}{ Without Chargeoffs } & With Chargeoffs \\
\hline Variable & Coefficient & t-stat & .03 & t-stat \\
\hline Intercept $\mathrm{a}_{0}$ & .01 & 0.41 & 9.06 & .94 \\
\hline sgNI, $\mathrm{a}_{1}$ & 8.76 & 4.76 & 1.32 & 5.01 \\
\hline $\mathrm{NBV}, \mathrm{a}_{2}$ & 1.32 & 3.62 & 12.75 & 3.68 \\
\hline sChgoff, $\mathrm{a}_{3}$ & & & & 2.98 \\
\hline Adj. $\mathrm{R}^{2}$ & & 17.47 & & 20.50 \\
\hline
\end{tabular}

2004, N-209

\begin{tabular}{|c|c|c|c|c|}
\multicolumn{2}{|c}{ Without Chargeoffs } \\
\hline Variable & Coefficient & t-stat & Coefficient & t-stat \\
\hline Intercept $\mathrm{a}_{0}$ & .06 & 3.43 & .07 & 4.15 \\
\hline sgNI, $\mathrm{a}_{1}$ & 5.50 & 5.30 & 6.32 & 6.19 \\
\hline NBV $\mathrm{a}_{2}$ & 0.91 & 5.90 & .84 & 5.62 \\
\hline sChgoff, $\mathrm{a}_{3}$ & & & 10.15 & 4.08 \\
\hline Adj. $\mathrm{R}^{2}$ & & 25.44 & & 30.72 \\
\hline
\end{tabular}

2005, N- 218

\begin{tabular}{|c|c|c|c|c|}
\hline \multicolumn{3}{|c|}{ Without Chargeoffs } & \multicolumn{2}{|c|}{ With Chargeoffs } \\
\hline Variable & Coefficient & t-stat & Coefficient & t-stat \\
\hline Intercept $\mathrm{a}_{0}$ & .06 & 2.90 & .06 & 3.21 \\
\hline sgNI, $a_{1}$ & 5.84 & 5.74 & 7.19 & 7.09 \\
\hline $\mathrm{NBV}, \mathrm{a}_{2}$ & 0.81 & 4.38 & .75 & 4.27 \\
\hline sChgoff, $\mathrm{a}_{3}$ & & & 11.77 & 4.63 \\
\hline Adj. $R^{2}$ & & 21.91 & & 28.67 \\
\hline
\end{tabular}

\section{AUTHOR INFORMATION}

Dr. Charles Harter is a professor at Georgia Southern University. He earned his Ph.D. in accounting from the University of Nebraska-Lincoln and his master's degree in finance from the University of Wyoming. Chuck has published in a variety of accounting and finance journals including the Journal of Accounting, Auditing, and Finance, Journal of Business, Finance and Accounting, Journal of Accounting Education, and The Journal of Accountancy. He is a CPA and a member of the AICPA, Georgia Society of CPAs, and the American Accounting Association.

\section{REFERENCES}

1. Brown, S, K. Lo, and T. Lys, (1999) "Use of $\mathrm{R}^{2}$ in Accounting Research: Measuring Changes in Value Relevance Over the Last Four Decades," Journal of Accounting and Economics 28 (1) pp. 83-115.

2. Chiang, R. and P. Venkatesh, (1988) "Insider Holdings and Perceptions of Information Asymmetry: A Note,” The Journal of Finance 43 (4) pp. 1041-1048. 
3. Collins, D., E. Maydew, and I. Weiss, (1997) "Changes in the Value Relevance of Earnings and Book Values Over the Past Forty Years," Journal of Accounting and Economics 24 (1) pp. 39-67.

4. Collins, D., M. Pincus, and H. Xie, (1999) "Equity Valuation and Negative Earnings: The Role of Book Value of Equity," The Accounting Review, 74 (1) pp. 29-61.

5. FASB Concepts Statement No. 7, Using Cash Flow Information and Present Value in Accounting Measurements, February 2000.

6. FASB Statement no. 115, Accounting for Certain Investments in Debt and Equity Securities, May, 1993.

7. FASB Statement no. 133, Accounting for Derivative Instruments and Hedging Activities, June 1998.

8. $\quad$ FASB Statement no. 144, Accounting for the Impairment or Disposal of Long-Lived Assets, August 2001.

9. $\quad$ FASB Statement no. 157, Fair Value Measurements, September 2006.

10. Francis, J. and K. Schipper, (1999) “Have Financial Statements Lost Their Relevance?” Journal of Accounting Research 37 (2) pp. 319-352.

11. Lev, B and P. Zarowin, (1999) "The Boundaries of Financial Reporting and How to Extend Them," Journal of Accounting Research, 37 (2) pp. 353-386.

12. Ohlson, J. (1995) “Earnings, Book Values, and Dividends in Security Valuation," Contemporary Accounting Research, 11 (2) pp. 661-688.

13. White, Lawrence J., (1991) “The Value of Market Value Accounting for the Deposit Insurance System," Journal of Accounting Auditing \& Finance, pp. 289-302, Spring 1991. 